\title{
Ethanolic leaf extract of Ipomoea aquatica Forsk abrogates cisplatin-induced kidney damage in albino rats
}

\author{
Bonsome Bokolo $^{1}{ }^{\circledR}$, Elias Adikwu ${ }^{2^{*} \odot ~}$ \\ ${ }^{1}$ Department of Pharmacology, Faculty of Basic Medical Sciences, Niger Delta University, Nigeria \\ ${ }^{2}$ Department of Pharmacology and Toxicology, Faculty of Pharmacy, Niger Delta University, Nigeria
}

\section{A R T I C L E I N F O}

\section{Article Type:}

Original

\section{Article History:}

Received: 5 September 2018

Accepted: 10 October 2018

ePublished: 6 November 2018

\section{Keywords:}

Cisplatin

Kidney

Toxicity

Ipomoea aquatica

Protection

Nephrotoxicity

\begin{abstract}
A B S T R A C T
Introduction: The efficacy of cisplatin (CPT) is dose dependent, but the risk of nephrotoxicity hinders the use of higher doses to maximize its antineoplastic effect. Ipomoea aquatica Forsk (IA) is a medicinal plant used in folklore for the treatment of many ailments.

Objectives: This study assessed the protective effect of the ethanolic leaf extract of I. aquatica (EEIA) against a rat model of CPT-induced kidney damage.

Materials and Methods: Fifty-four adult albino rats used for this study were randomized into 9 groups of 6 rats each. Rats were orally pretreated with 100, 200 and $400 \mathrm{mg} / \mathrm{kg}$ of EEIA daily for 7 days and were administered with $6 \mathrm{mg} / \mathrm{kg}$ of CPT intraperitoneally (ip) on the fifth and seventh day. On the eighth day, rats were sacrificed, blood was collected, and kidneys were excised. Plasma was extracted from blood and evaluated for renal function indices while kidneys were evaluated for oxidative stress markers and histology.

Results: The effects of CPT on the body and kidney weights were not significant $(P>0.05)$ when compared to control. However, CPT-induced kidney damage showed significant $(P<0.05)$ increases in creatinine, urea, uric acid, and malondialdehyde levels when compared to control. Furthermore, significant $(P<0.05)$ decreases in superoxide dismutase, catalase, glutathione, glutathione peroxidase, total protein, albumin, sodium, chloride, potassium and bicarbonate levels were obtained in CPT-treated rats when compared to control. The kidneys of CPTtreated rats were marked by extensive tubular necrosis. However, CPT-induced nephrotoxic effects were significantly $(P<0.01 ; 0.05)$ and in a dose- dependent manner reversed in EEIA pretreated rats.

Conclusion: The ethanolic leaf extract of I. aquatica Forsk contains essential constituents that can be used to treat CPT associated kidney injury.
\end{abstract}

Implication for health policy/practice/research/medical education:

This study evaluated the protective effect of the ethanolic leaf extract of I. aquatica against a rat model of cisplatin-induced kidney damage. This study observed that the ethanolic leaf extract of I. aquatica attenuate cisplatin-induced kidney damage in a dosedependent manner. This shows that the ethanolic leaf extract of I. aquatica contains essential constituents that can be used for the treatment cisplatin associated kidney damage.

Please cite this paper as: Bokolo B, Adikwu E. Ethanolic leaf extract of Ipomoea aquatica Forsk abrogates cisplatin-induced kidney damage in albino rats. J Nephropharmacol. 2019;8(1):e02. DOI: 10.15171/npj.2019.02

\section{Introduction}

Cisplatin (CPT) is a very effective chemotherapeutic platinum compound used for the treatment of cancer (1). It is useful for the treatment of cancers of the head, neck, ovary, testis, and lung (2). However, the use of CPT in combating cancer is limited by the development of numerous reversible and irreversible adverse effects (3). The efficacy of CPT is dose dependent, but the significant risk of nephrotoxicity frequently hinders the use of higher doses to maximize its antineoplastic effect (4). The kidney excretes CPT. However, on entering the kidney, it is concentrated in the renal tubular cells via organic cation transporter 2 (5) where it undergoes metabolic activation to a more potent toxin (6). Nephrotoxicity due to CPT is characterized by tubular damage, affecting renal proximal and distal tubules. Tubular damage may range from a mere loss of brush border of epithelial cells to an overt tubular necrosis in severe cases. Tubular damage causes impaired reabsorption, which underlies the proteinuria, hypomagnesemia and hypokalemia observed with CPT 
administration. In addition, nephrotoxicity due to CPT often progresses with reduced glomerular filtration rate and increased serum creatinine and urea (7). The mechanism of CPT-induced nephrotoxicity is not fully understood. However, some studies suggest the induction of oxidative stress (8), leading to epithelial cell damage, injury to nuclear and mitochondrial DNA, activation of multiple cell death, survival pathways and the initiation of inflammatory response (9).

Ipomoea aquatica (IA) which belongs to family Convolvulaceae is a perennial herb found throughout Asia and Africa. It is considered to have a wide distribution and grows in moist soils as well as the side-lines of fresh water, ditches, lakes, ponds, marshes and wet rice field (10). It is used in folklore for the treatment of many ailments, which include inflammation, fever, jaundice, biliousness, and bronchitis. In addition, it is used for the treatment of febrile delirium, piles, hypertension, diabetes, constipation, and microbial infections (10). Pharmacological evaluations in animal model have shown that it has anti-diabetic, anti-inflammatory, anti-hypertensive, antimicrobial, anticancer and antioxidant activities(10). The basic preliminary phytochemical screening of IA shows the presence of various phytochemicals such as flavonoids, amino acids, alkaloids, lipids, steroids, saponin, phenols, reducing sugar, tannins, $\beta$-carotene, glycosides, and quercetin (11). Phenolics, flavonoids and tannins, are natural antioxidants with potential role in the prevention and treatment of diseases (12). Flavonoids are a group of natural poly-phenolic compounds found in plants and have a variety of biological effects and play important roles in the detoxification of free radicals and can prevent drug-induced nephrotoxicity (13).

\section{Objectives}

The present study evaluated the effect of the ethanolic leaf extract of Ipomoea aquatica Forks (EEIA) on CPTinduced kidney damage in albino rats which has not been evaluated.

\section{Materials and Methods}

\section{Animals, drugs and preparation of plant material} Fifty-four adult albino rats of either sex, weighing 210$225 \mathrm{~g}$, purchased from the animal house of the Faculty of Pharmacy, Madonna University, Elele were used for this study. Rats were divided into 9 groups of six rats each housed in cages under a $12 \mathrm{~h}$ light/ dark cycle and had free access to diet and water ad libitum. The rats were allowed to acclimatize for one week. CPT injection (Sun Pharmaceutical India) was used to induce renal toxicity. The leaves of Ipomoea aquatica Forks (IA) were harvested and authenticated. The leaves of IA were cleaned and dried in shade and powdered by a mechanical grinder. For the preparation of ethanolic extract, $350 \mathrm{~g}$ of IA powder was added to $1000 \mathrm{~mL}$ of ethanol and macerated for 24 hours and filtered. The extract was filtered through Whatman
No. 1 paper and evaporated under reduced pressure using a rotary evaporator to an extract. The yield (40.9 g) was kept in a bottle with a tight-fitting cover until it was needed for the study.

Phytochemical analysis of Ipomoea aquatica Forsk The tests for carbohydrate, protein, tannins, saponins, steroids, flavonoids, terpenoids, alkaloids, and glycosides were carried out based on procedures outlined by Trease and Evans (14).

Dose selection, drug administration and animal sacrifice CPT (6 mg/kg) intraperitoneally (ip) was used for the induction of nephrotoxicity (15) while 100, 200 and 400 $\mathrm{mg} / \mathrm{kg}$ of EEIA were used for the study (16). Group A (solvent control) was treated with $0.2 \mathrm{~mL}$ of normal saline whereas group B (placebo control) was treated with 0.2 $\mathrm{mL}$ of corn oil. Groups C-E were orally treated with 100 , 200 and $400 \mathrm{mg} / \mathrm{kg}$ of EEIA daily for 7 days respectively. Group F was treated with $6 \mathrm{mg} / \mathrm{kg}$ of CPT intraperitoneally (ip) on the fifth and seventh day. Groups G-I were orally pretreated with 100, 200 and $400 \mathrm{mg} / \mathrm{kg}$ of EEIA daily for 7 days respectively while $6 \mathrm{mg} / \mathrm{kg}$ of CPT was administered ip on the fifth and seventh day. The rats were allowed for an overnight fast and sacrificed on the eighth day.

\section{Biochemical and antioxidant assay}

Blood was obtained after the rats were euthanized and centrifuged at $4000 \mathrm{rpm}$ for 15 minutes. The resulting plasma was analyzed for renal function indexes (creatinine, urea, uric acid, total protein and albumin) using standard laboratory test kits. Kidneys were harvested, weighed and homogenized with $10 \mathrm{~mL}$ of sucrose solution $(0.25$ M) using electric homogenizer. The homogenate was centrifuged at $3000 \mathrm{rpm}$ for 20 minutes and the supernatant was collected for the assessment of antioxidant levels. Kidney malondialdehyde was assayed according to Buege and Aust (17) while reduced glutathione was evaluated using the method of Sedlak and Lindsay (18). Superoxide dismutase was assessed as reported by Sun and Zigma (19) while catalase was analyzed as described by Aebi (20). Glutathione peroxidase was evaluated as reported by Rotruck et al (21) while total protein was measured as described by Gornall et al (22).

\section{Histological examination of the kidney}

Kidney samples were taken and fixed in $10 \%$ neutral buffered formalin for 24 hours and decalcification was carried out using formic acid. The kidneys were dehydrated in serial dilutions of alcohol. Kidney specimens were cleared in xylene and embedded in paraffin. Paraffin wax tissue blocks were prepared for sectioning at $4 \mu \mathrm{m}$ thicknesses by a sledge microtome. The obtained tissue sections were collected on glass slides, deparaffinized, stained with hematoxylin and eosin, and then examined using light electric microscope for pathology. 


\section{Ethical issues}

This project was approved by Ethics Committee of Niger Delta University, Bayelsa State Nigeria. Prior to the experiment, the protocols were confirmed to be in accordance with the guidelines of Animal Ethics Committee of Niger Delta University.

Statistical analysis

Statistical analysis was performed using SPSS 18 software (SPSS Inc, Chicago, IL). Results are presented as mean \pm standard error of mean (SEM). Differences among groups were conducted using ANOVA followed by Tukey's post hoc test. Values of $P<0.05 ; 0.01$ were considered significant.

\section{Results}

The phytochemical analysis of EEIA shows the presence of the following constituents; tannins, saponins, flavonoids, alkaloids, protein, phenols, glycosides and carbohydrate. Rats administered with CPT and EEIA did not show significant $(P>0.05)$ changes in body and kidney weights in comparison to control (Table 1). Also, effects were not significant $(P>0.05)$ on plasma creatinine, urea, uric acid, total protein and albumin in rats administered with EEIA when compared to control. On the contrary, plasma creatinine, urea and uric acid were significantly $(P<0.05)$ increased whereas total protein and albumin levels were significantly $(P<0.05)$ decreased in CPT administered rats when compared to control (Table 2). However, the levels of these plasma parameters were significantly $(P<0.01 ; 0.05)$ reversed in a dose dependent manner in rats pretreated with EEIA prior to the administration of CPT (Table 2). Furthermore, in rats treated with EEIA, plasma sodium, chloride, potassium and bicarbonate levels were not significantly $(P>0.05)$ different from the control. However, lower and significant $(P<0.05)$ levels of plasma sodium, chloride, potassium and bicarbonate were observed in CPT-treated rats when compared to control. On the other hand, these parameters were significantly $(P<0.01 ; 0.05)$ restored in a dose-dependent manner in EEIA pretreated rats (Table 3). In EEIA treated rats, the kidney levels of malondialdehyde (MDA), glutathione (GSH), catalase (CAT), superoxide dismutase (SOD) and glutathione peroxidase (GPX) did not differ significantly $(P>0.05)$ from the control. On the contrary, SOD, CAT, GSH and GPX levels were significantly $(P<0.05)$ decreased whereas MDA levels were significantly $(P<0.05)$ increased in CPTtreated rats when compared to control (Table 4). However, the kidney levels of these parameters were significantly $(P<0.01 ; 0.05)$ reversed in a dose-dependent manner in rats pretreated with EEIA prior to the administration of CPT (Table 4). The micrograph of the kidney of the control

Table 1. Effects of Ipomoea aquatica on body and kidney weights of cisplatin-treated albino rats

\begin{tabular}{|c|c|c|c|c|}
\hline Dose (mg/kg) & Initial body weight (g) & Final body weight (g) & Kidney weight (g) & Relative kidney weight (\%) \\
\hline Control & $220.7 \pm 12.0$ & $230.5 \pm 12.3$ & $0.76 \pm 0.07$ & $0.32 \pm 0.03$ \\
\hline EEIA 100 & $210.5 \pm 13.1$ & $221.6 \pm 11.9$ & $0.80 \pm 0.02$ & $0.36 \pm 0.09$ \\
\hline EEIA 200 & $225.4 \pm 11.5$ & $235.0 \pm 12.1$ & $0.75 \pm 0.05$ & $0.32 \pm 0.04$ \\
\hline EEAA 400 & $215.3 \pm 10.3$ & $222.4 \pm 13.2$ & $0.82 \pm 0.04$ & $0.37 \pm 0.03$ \\
\hline CPT 6 & $225.9 \pm 12.6$ & $235.6 \pm 10.4$ & $0.76 \pm 0.07$ & $0.32 \pm 0.08$ \\
\hline EEIA $100+$ CPT & $220.5 \pm 10.1$ & $229.7 \pm 11.2$ & $0.81 \pm 0.03$ & $0.35 \pm 0.04$ \\
\hline EEIA200 + CPT & $225.1 \pm 13.2$ & $232.5 \pm 12.8$ & $0.84 \pm 0.06$ & $0.36 \pm 0.02$ \\
\hline EEIA400 + CPT & $220.8 \pm 12.7$ & $230.9 \pm 13.3$ & $0.79 \pm 0.03$ & $0.34 \pm 0.07$ \\
\hline
\end{tabular}

EEIA, ethanolic leaf extract of Ipomoea aquatica; CPT, cisplatin.

Values are represented as mean $\pm S E M, n=6$.

Table 2. Effect of Ipomoea aquatica on plasma renal function indices of cisplatin-treated albino rats

\begin{tabular}{|c|c|c|c|c|c|}
\hline Dose (mg/kg) & Urea (mg/dL) & Creatinine (mg/dL) & Uric acid (mg/dL) & Total protein (g/dL) & Albumin (g/dL) \\
\hline Control & $28.3 \pm 2.22$ & $1.40 \pm 0.55$ & $1.32 \pm 0.17$ & $8.54 \pm 0.82$ & $5.44 \pm 0.35$ \\
\hline EEIA100 & $27.5 \pm 2.13$ & $1.37 \pm 0.40$ & $1.30 \pm 0.70$ & $8.55 \pm 0.53$ & $5.46 \pm 0.46$ \\
\hline EE1A 200 & $28.5 \pm 2.52$ & $1.35 \pm 0.31$ & $1.29 \pm 0.53$ & $8.59 \pm 0.40$ & $5.49 \pm 0.35$ \\
\hline EE1A 400 & $25.4 \pm 2.20$ & $1.34 \pm 0.23$ & $1.26 \pm 0.62$ & $8.60 \pm 0.59$ & $5.50 \pm 0.51$ \\
\hline СРТ6 & $98.1 \pm 8.11^{\mathrm{a}}$ & $6.70 \pm 0.32^{a}$ & $7.43 \pm 0.47^{\mathrm{a}}$ & $2.21 \pm 0.71^{\mathrm{a}}$ & $1.00 \pm 0.60^{a}$ \\
\hline $\mathrm{EE} 1 \mathrm{~A} 100+\mathrm{CPT}$ & $60.9 \pm 7.32^{b}$ & $4.32 \pm 0.72^{b}$ & $4.41 \pm 0.43^{b}$ & $3.71 \pm 0.56^{b}$ & $3.19 \pm 0.80^{b}$ \\
\hline EE1A $200+C P T$ & $42.4 \pm 4.14^{c}$ & $2.50 \pm 0.53^{c}$ & $3.62 \pm 0.79^{c}$ & $5.50 \pm 0.68^{c}$ & $4.65 \pm 0.41^{c}$ \\
\hline EE1A 400 + CPT & $29.8 \pm 2.63^{c}$ & $1.51 \pm 0.27^{c}$ & $1.48 \pm 0.62^{c}$ & $7.65 \pm 0.47^{c}$ & $5.37 \pm 0.72^{c}$ \\
\hline
\end{tabular}

EEIA, ethanolic leaf extract of Ipomoea aquatica; CPT, cisplatin.

Values are represented as mean $\pm S E M, n=6$.

a Significant $(P<0.05)$ difference when compared to control. ${ }^{\mathrm{b}}$ Significant $(P<0.05)$ difference when compared to CPT-treated rats. ${ }^{\mathrm{c}}$ Significant $(P<0.01)$ difference when compared to CPT-treated rats. 
Bokolo B and Adikwu E

Table 3. Effect of Ipomoea aquatica on plasma electrolytes of cisplatin-treated albino rats

\begin{tabular}{|c|c|c|c|c|}
\hline Dose (mg/kg) & $\mathrm{K}^{+}(\mathrm{mmo} / \mathrm{L})$ & $\mathrm{Cl}^{-}(\mathrm{mmo} / \mathrm{L})$ & $\mathrm{Na}^{+}(\mathrm{mmo} / \mathrm{L})$ & $\mathrm{HCO3}^{-}(\mathrm{mmo} / \mathrm{L})$ \\
\hline Control & $3.47 \pm 0.61$ & $121.0 \pm 10.5$ & $180.8 \pm 13.4$ & $26.4 \pm 2.24$ \\
\hline EEIA 100 & $3.46 \pm 0.59$ & $120.7 \pm 12.7$ & $187.3 \pm 14.0$ & $27.7 \pm 2.52$ \\
\hline EEIA 200 & $3.48 \pm 0.32$ & $125.9 \pm 11.0$ & $180.6 \pm 12.5$ & $25.3 \pm 2.00$ \\
\hline EEIA 400 & $3.40 \pm 0.44$ & $127.6 \pm 10.5$ & $185.7 \pm 13.7$ & $28.6 \pm 2.46$ \\
\hline СРT6 & $1.00 \pm 0.57^{a}$ & $40.9 \pm 3.96^{a}$ & $61.7 \pm 4.55^{a}$ & $10.4 \pm 1.00^{a}$ \\
\hline EEIA $100+$ CPT & $1.54 \pm 0.44^{b}$ & $61.9 \pm 4.22^{b}$ & $95.6 \pm 7.32^{b}$ & $14.7 \pm 1.17^{b}$ \\
\hline EEIA $200+$ CPT & $2.02 \pm 0.65^{c}$ & $90.6 \pm 7.57^{c}$ & $130.1 \pm 14.0^{c}$ & $21.0 \pm 2.51^{c}$ \\
\hline EEIA $400+$ CPT & $3.36 \pm 0.31^{c}$ & $110.5 \pm 10.7^{c}$ & $179.6 \pm 15.1^{c}$ & $25.2 \pm 2.63^{c}$ \\
\hline
\end{tabular}

EEIA, ethanolic leaf extract of Ipomoea aquatica; CPT, cisplatin.

Values are represented as mean $\pm \mathrm{SEM}, \mathrm{n}=6$.

a Significant $(P<0.05)$ difference when compared to control. ${ }^{\mathrm{b}}$ Significant $(P<0.05)$ difference when compared to CPT-treated rats. ${ }^{\mathrm{c}}$ Significant $(P<0.01)$ difference when compared to CPT-treated rats.

Table 4. Effect of Ipomoea aquatica on kidney oxidative stress indicators of cisplatin- treated albino rats

\begin{tabular}{|c|c|c|c|c|c|}
\hline Dose (mg/kg) & MDA (nmol/mgprotein) & GSH ( $\mu \mathrm{g} /$ mgprotein) & CAT (U/mgprotein) & SOD (U/mgprotein) & GPX ( $\mu \mathrm{g} / \mathrm{mgprotein})$ \\
\hline Control & $0.18 \pm 0.09$ & $14.7 \pm 0.43$ & $24.0 \pm 2.11$ & $35.0 \pm 4.00$ & $25.3 \pm 2.54$ \\
\hline EEIA 100 & $0.16 \pm 0.01$ & $16.2 \pm 0.31$ & $25.4 \pm 2.65$ & $37.1 \pm 3.17$ & $26.9 \pm 2.00$ \\
\hline EEIA 200 & $0.13 \pm 0.06$ & $15.6 \pm 1.00$ & $25.8 \pm 3.52$ & $36.6 \pm 2.58$ & $28.0 \pm 3.57$ \\
\hline EEIA 400 & $0.12 \pm 0.03$ & $17.0 \pm 2.17$ & $27.0 \pm 4.32$ & $39.7 \pm 3.11$ & $29.1 \pm 3.36$ \\
\hline CPT6 & $3.00 \pm 0.08^{a}$ & $4.16 \pm 0.33^{a}$ & $6.06 \pm 0.21^{a}$ & $9.32 \pm 0.24^{\mathrm{a}}$ & $5.05 \pm 0.14^{a}$ \\
\hline EEIA $100+$ CPT & $2.53 \pm 0.04^{b}$ & $6.53 \pm 0.47^{b}$ & $9.42 \pm 1.11^{b}$ & $15.4 \pm 2.07^{b}$ & $8.1 \pm 0.28^{b}$ \\
\hline EEIA $200+$ CPT & $1.42 \pm 0.03^{c}$ & $9.72 \pm 0.24^{c}$ & $14.6 \pm 1.52^{c}$ & $22.5 \pm 3.20^{c}$ & $14.2 \pm 1.00^{c}$ \\
\hline EEIA 400+ CPT & $0.31 \pm 0.05^{c}$ & $13.1 \pm 0.57^{c}$ & $20.7 \pm 2.00^{c}$ & $30.2 \pm 2.70^{c}$ & $20.9 \pm 2.31^{c}$ \\
\hline
\end{tabular}

EEIA, ethanolic leaf extract of Ipomoea aquatica; CPT, cisplatin.

Values are represented as mean $\pm \mathrm{SEM}, \mathrm{n}=6$.

a Significant $(P<0.05)$ difference when compared to control. ${ }^{b}$ Significant $(P<0.05)$ difference when compared to $C P T$-treated rats. ${ }^{c}$ Significant $(P<0.01)$ difference when compared to CPT-treated rats.

rat showed normal histology (Figure 1A). Additionally, the micrograph of the kidney of rats administered with $400 \mathrm{mg} / \mathrm{kg}$ of EEIA showed normal histology (Figure 1B). In contrast, the kidney of rat administered with CPT showed extensive tubular necrosis (Figure 1C). However, the kidneys of rats pretreated with 100, 200 and $400 \mathrm{mg} / \mathrm{kg}$ of CPT prior to the administration of CPT showed acute tubular necrosis (Figures $1 \mathrm{D}$ to $1 \mathrm{~F}$ ).

\section{Discussion}

The phytochemical screening of EEIA shows the presence of tannin, saponins, flavonoids, alkaloids, protein, phenols, glycosides and carbohydrate. This observation is in agreement with previous findings (23). The comparison between organ weights of treated and untreated groups of animals has conventionally been used to evaluate the toxic effects of chemical substances (24). The present study did not observe significant changes in the body and kidney weights of rats administered with CPT and EEIA. Creatinine is a non-protein nitrogenous waste product produced from the breakdown of creatine and phosphocreatine which serves as an indicator of renal function (25). Urea is a sensitive biomarker used in the assessment of renal tissue damage (26). Uric acid is the final oxidation product of purine metabolism and is renally excreted. Its level is usually elevated in kidney disease
(27). In the present study, the plasma levels of creatinine, urea and uric acid were normal in rats administered with EEIA. However, the plasma levels of these parameters were elevated in CPT treated rats. This observation is consistent with previous findings (28). On the other hand, elevations in the plasma levels of creatinine, urea and uric acid in CPT treated rats were abrogated in a dose dependent fashion in rats pretreated with EEIA. The quantification of proteinuria (the majority of which is usually albumin) is now a central part of screening for kidney disease (29). This study observed normal levels of plasma total protein and albumin in EEIA-treated rats. On the contrary, the levels of total protein and albumin were abnormally decreased in CPT-treated rats. This finding is in agreement with previous study (30). However, this observation was abrogated in a dose-dependent fashion in rats pretreated with EEIA. Plasma electrolytes play important physiological roles in enhancing enzyme activities, creating electrical gradients, promoting several metabolic and cellular activities, and ensuring normal homeostasis. Therefore, distortions in electrolytes may lead to clinical abnormalities (31). The current study observed normal levels of plasma electrolytes (sodium, chloride, potassium and bicarbonate) in EEIA administered rats. However, plasma electrolytes were decreased in CPT-treated rats. This is in line with previous reports (32). In contrast, 

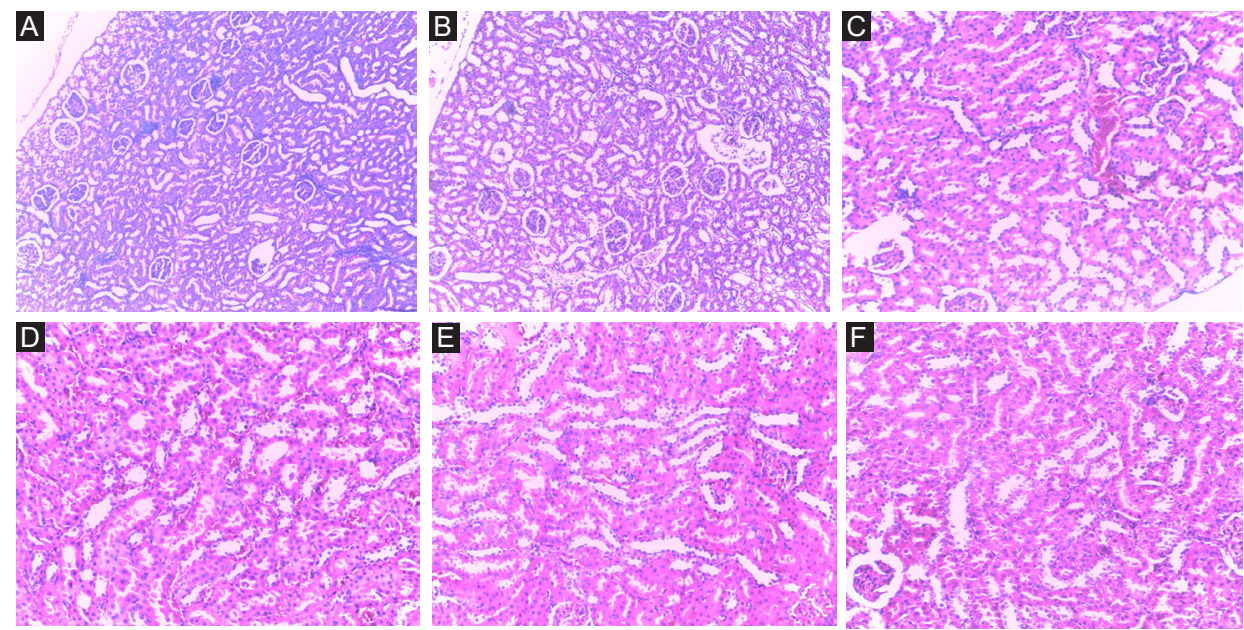

Figure 1. (A) Kidney of the control rat showing normal histology. (B) Kidney of rat administered orally with $400 \mathrm{mg} / \mathrm{kg}$ of ethanolic leaf extract of Ipomoea aquatica daily for 7 days showing normal histology. (C) Kidney of rat administered with 6 mg/kg of CPT intraperitoneally showing extensive tubular necrosis. (D-F) Kidneys of rats pretreated orally with 100, 200 and $400 \mathrm{mg} / \mathrm{kg}$ of the ethanolic leaf extract of Ipomoea aquatica for 7 days prior to the administration of $6 \mathrm{mg} / \mathrm{kg}$ of CPT intraperitoneally showing acute tubular necrosis (H\&E 100X).

plasma electrolytes were restored in EEIA pretreated rats. The main enzymes participating in oxidative stress reduction process are SOD, CAT, GSH and GPX. SOD and CAT are collectively involved in the degradation of superoxide anion to hydrogen peroxide and finally to water (33). GPX decreases hydrogen peroxide and transforms lipoperoxide and other organic hydroperoxides into their corresponding less reactive hydroxylated compounds (34). These enzymes form a frontline defense against oxidative stress; therefore, decreases in their activities may result in several deleterious effects (35).

In the current study, EEIA treated rats showed normal kidney SOD, CAT, GSH and GPX levels. However, CPT treated rats showed decreased SOD, CAT, GSH and GPX levels. The observation in CPT treated rats is consistent with previous reports (36). On the other hand, the levels of SOD, CAT, GSH and GPX were restored in a dose dependent fashion in rats pretreated with EEIA. MDA is one of the most abundant aldehyde generated during secondary lipid oxidation that is commonly used as a lipid peroxidation marker. It is highly toxic and can alter or cross-link a variety of biological macromolecules producing mutagenic/carcinogenic effects (37). In this study, normal MDA levels were observed in EEIA-treated rats, in contrast, elevated levels of MDA were observed in CPT treated rats. The observation in CPT treated rats has been previously reported (38). However, MDA levels were restored in EEIA pretreated rats. It is imperative that CPTinduced alterations in biochemical indices be correlated with renal histology. Therefore, the kidneys of CPT treated rats were examined and results showed extensive tubular necrosis. This observation is in agreement with previous reports (39). However, the observed kidney damage in CPT treated rats was ameliorated in EEIA pretreated rats. The mechanism of CPT-induced nephrotoxicity is not fully understood (40). However, renal tubular injury and death (apoptosis and necrosis) were the main pathological events reported in CPT associated nephrotoxicity (41). CPT is known to damage cell mitochondria, arrest cell cycle in the G2 phase, inhibit ATPase activity and alter cellular transport system. These actions can eventually induce apoptosis, necrosis and cell death (41). It has also been proposed that CPT binds to GSH resulting in CPTGSH complex formation in tubules stimulating renal lipid peroxidation (42). CPT interacts with thiol groups and macromolecules and causes significant oxidant loading on the kidney resulting in accelerated oxidative and nitrosative stress (43). In the present study, the observed ameliorative effect of EEIA against CPT-induced renal toxicity is in consonance with the protective effect of EEIA on gentamicin-induced renal toxicity in albino rats reported by Sharmin et al (44). The ameliorative effect of EEIA could be attributed to its ability to inhibit CPTinduced oxidative and nitrosative stress in renal tissues of treated rats. Studies showed that EEIA has the ability to scavenge free radicals, up-regulate antioxidant activities and inhibits the production of pro-inflammatory mediators. These effects have been attributed to its phytochemical constituents especially phenolics, flavonoids, $\beta$-carotene and tannins. $\beta$-carotene has been reported to have antioxidant and anti-inflammatory effects (45). Flavonoids can quench free radicals, suppress enzymes associated with free radical generation and stimulate internal antioxidants (46). Phenolic compounds scavenge free radicals, donate hydrogen and serve as reducing agents $(47,48)$.

\section{Conclusion}

The ethanolic leaf extract of I. aquatica Forsk contains essential phytochemical substances that can ameliorate 
CPT associated kidney injury.

\section{Acknowledgments}

The authors appreciate the technical assistance of Eze Ihekumere of the animal house of the Faculty of Pharmacy Madonna University, Nigeria.

\section{Authors' contribution}

EA: Concept and design of the study, literature search, collection of data, statistical analysis, manuscript preparation and critical revision of the manuscript; BB: Concept, collection of data, review of the literature, preparation of first manuscript draft and critical revision of the manuscript.

\section{Conflicts of interest}

The authors declared no competing interests.

\section{Ethical considerations}

Ethical issues which include plagiarism, data fabrication, double publication have been completely observed by the authors.

\section{Funding/Support}

None.

\section{References}

1. Katzung BG. Basic and Clinical Pharmacology. New York: McGraw-Hill. 2004. p. 906.

2. Hayati F, Hossainzadeh M, Shayanpour S, AbediGheshlaghi Z, Beladi Mousavi SS. Prevention of cisplatin nephrotoxicity. J Nephropharmacol. 2015;5:57-60.

3. Nitha B, Janardhanan KK. Aqueous-ethanolic extract of morel mushroom mycelium Morchella esculenta, protects cisplatin and gentamicin induced nephrotoxicity in mice. Food Chem Toxicol. 2008;46:3193-9. doi: 10.1016/j. fct.2008.07.007.

4. Hanigan $\mathrm{MH}$, Devarajan P. Cisplatin nephrotoxicity: molecular mechanisms. Cancer Ther. 2003;1:47-61.

5. Yao X, Panichpisal K, Kurtzman N, Nugent K. Cisplatin nephrotoxicity: a review. Am J Med Sci. 2007;334:115-24. doi: 10.1097/MAJ.0b013e31812dfe1e.

6. Yonezawa A, Masuda S, Yokoo S, Katsura T, Inui K. Cisplatin and oxaliplatin, but not carboplatin and nedaplatin, are substrates for human organic cation transporters (SLC22A1-3 and multidrug and toxin extrusion family). J Pharmacol Exp Ther. 2006;319:879-86. doi: 10.1124/ jpet.106.110346.

7. Dobyan DC, Levi J, Jacobs C, Kosek J, Weiner MW. Mechanism of cisplatinum nephrotoxicity: II. Morphologic observations. J Pharmacol Exp Ther. 1980;213:551-6.

8. Nasri H. Cisplatin therapy and the problem of genderrelated nephrotoxicity. J Nephropharmacol. 2013;2:13-14.

9. Kaushal GP, Kaushal V, Hong X, Shah SV. Role and regulation of caspases in cisplatin-induced injury to renal tubular epithelial cells. Kidney Int. 2001;60:1726-36. doi: 10.1046/j.1523-1755.2001.00026.x.

10. Malakar C, Choudhury PPN. Pharmacological potentiality and medicinal uses of Ipomoea aquatica Forsk: a review. Asian J Pharm Clin Res. 2015;8:60-63.

11. Igwenyl IO, Offor CE, Ajah DA, Nwankwo OC, Ukaomah JI, Aja PM. Chemical composition of Ipomoea aquatica (Green Kangkong). Int J Pharma Bio Sci. 2011;2:594597.

12. Ajith TA, Aswathy MS, Hema U. Protective effect of Zingiber officinale roscoe against anticancer drug doxorubicininduced acute nephrotoxicity. Food Chem Toxicol. 2008;46:3178-81. doi: 10.1016/j.fct.2008.07.004.

13. AlSharari SD, Al-Rejaie SS, Abuohashish HM, Ahmed MM, Hafez MM. Rutin attenuates hepatotoxicity in highcholesterol-diet-fed rats. Oxidative med Cell Longev. 2016;2016:5436745. doi: 10.1155/2016/5436745.

14. Trease GE, Evans WC. A Text-book of Parmacognosy. London: Bailliere Tindall Ltd; 1989. p. 53.

15. Mika D, Guruvayoorappan C. The effect of Thespesia populnea on cisplatin induced nephrotoxicity. J Cancer Res Ther. 2013;9:50-3. doi: 10.4103/0973-1482.110362.

16. AlkiyumiSS, Abdullah MA, Alrashdi AS, Salama SM, Abdelwahab SI, Hadi AH. Ipomoea aquatica extract shows protective action against thioacetamide-induced hepatotoxicity. Molecules. 2012;17:6146-55. doi: 10.3390/ molecules17056146.

17. Buege JA, Aust SD. Microsomal lipid peroxidation. Methods Enzymol.1978;52:302-10.

18. Sedlak J, Lindsay RH. Estimation of total, proteinbound, and nonprotein sulfhydryl groups in tissue with Ellman'seeagent. Anal Biochem. 1968;25:192-205.

19. Sun M, Zigma S. An Improved spectrophotometer assay of superoxide dismutase based on epinephrine antioxidation. Anal Biochem. 1978;90:81-9. doi: 10.1016/00032697(78)90010-6.

20. Aebi H. Catalase in vitro. Methods Enzymol. 1984;105:1216.

21. Rotruck JT, Pope AL, Ganther HE, Swanson AB, Hafeman DG, Hoekstra WG. Selenium: biochemical role as a component of glutathione peroxidase. Science. 1973;179:588-90.

22. Gornall AG, Bardawill CJ, David MM. Determination of serum proteins by means of the biureto reaction. J Biol Chem. 1949;177:751-66.

23. Khatun CS, Islam MA, Azad MAK, Ali MA, Hassan MF, Wahidunnobi M, et al. Antibacterial, antidiabetic and lipid lowering effects of ethanolic extract of Ipomoea aquatic. Banglad J Microbiol. 2012;29:50-54.

24. Bailey SA, Zidell RH, Perry RW. Relationships between organ weight and body/brain weight in the rat: What is the best analytical endpoint? Toxicol Path. 2004;32:448-66. doi: 10.1080/01926230490465874.

25. Price CP, Finney H. Developments in the assessment of glomerular filtration rate. Clin Chim Acta. 2000;297:55-66. doi: 10.1016/S0009-8981(00)00233-3.

26. Oyewole OI. Chemopreventive role of vitamin $\mathrm{C}$ and $\mathrm{E}$ on potassium bromated induced renal oxidative damage in rat. J Med Med Sci. 2011;2:1189-1192.

27. Johnson RJ, Lanaspa MA, Gaucher EA. Uric acid: a danger signal from the RNA world that may have a role in the epidemic of obesity, metabolic syndrome, and cardiorenal disease: evolutionary considerations. Semin Nephrol. 2011;31:394-9. doi: 10.1016/j.semnephrol.2011.08.002. 
28. Danduga RCR, Kumar GS, Kumar KP, Swamy BMV, Kishore KV. Nephroprotective activity of Cissampelos pareira Linn extract against cisplatin induced nephrotoxic rats. Am J Pharm Tech Res. 2015;5:480-488.

29. Waikar SS, Sabbisetti VS, Bonventre JV. Normalization of urinary biomarkers to creatinine during changes in glomerular filtration rate. Kidney Int. 2010;78:486-94. doi: 10.1038/ki.2010.165.

30. Nanji AA, Mikhael NZ, Stewart DJ. Hypoalbuminemia in patients receiving cisplatin: correlation between liver platinum and decrease in serum albumin. Oncology. 1986;43:33-5. doi: 10.1159/000226100.

31. Liamis G, Rodenburg EM, Hofman A, Zietse R, Stricker $\mathrm{BH}$, Hoorn EJ. Electrolyte disorders in community subjects: prevalence and risk factors. Am J Med. 2013;126:256-63. doi: 10.1016/j.amjmed.2012.06.037.

32. Adeneye AA, Benebo AS. Chemopreventive effect of tadalafil in cisplatin-induced nephrotoxicity in rats. Niger J Physiol Sci. 2016;31:1-10.

33. Martinez-Hervas S, Fandos M, Real JT, Espinosa O, Chaves FJ, Saez GT, et al. Insulin resistance and oxidative stress in familial combined hyperlipidemia. Atherosclerosis. 2008;199:384-9. doi: 10.1016/j.atherosclerosis.2007.11.023.

34. Roberts CK, Sindhu KK. Oxidative stress and metabolic syndrome. Life Sci. 2009;84:705-12. doi: 10.1016/j. lfs.2009.02.026.

35. Al-azzawie HF, Umran A, Hyader NH. Oxidative stress, antioxidant status and DNA damage in a mercury exposure workers. Br J Pharmacol Toxicol. 2013;4:80-88.

36. Fouad AA, Al-Sultan AI, Refaie SM, Yacoubi MT. Coenzyme Q10 treatment ameliorates acute cisplatin nephrotoxicity in mice. Toxicology. 2010;274:49-56. doi: 10.1016/j.tox.2010.05.007.

37. Janero DR. Malondialdehyde and thiobarbituric acidreactivity as diagnostic indices of lipid peroxidation and peroxidative tissue injury. Free Radic Biol Med. 1990;9:51540. doi: 10.1016/0891-5849(90)90131-2.

38. Palipoch S, Punsawad C. Biochemical and histological study of rat liver and kidney injury induced by cisplatin. J
Toxicol Pathol. 2013;26:293-9. doi: 10.1293/tox.26.293.

39. Shirwaikar A, Malini S, Kumari SC. Protective effect of Pongamia pinnata flowers against cisplatin and gentamicin induced nephrotoxocity in rats. Indian J Exp Biol. 2003;41:58-62.

40. Pabla N, Dong Z. Cisplatin nephrotoxicity: mechanisms and renoprotective strategies. Kidney Int. 2008;73:9941007. doi: 10.1038/sj.ki.5002786.

41. Hajian S, Rafieian-Kopaei M. Nasri H. Renoprotective effects of antioxidants against cisplatin nephrotoxicity. cisplatin nephrotoxicity. J Nephropharmacol. 2014;3: 39-42.

42. Townsend DM, Tew KD, He L, King JB, Hanigan MH. Role of glutathione S-transferase $\mathrm{Pi}$ in cisplatin-induced nephrotoxicity. Biomed Pharmacother. 2009;63:79-85. doi: 10.1016/j.biopha.2008.08.004.

43. Cetin R, Devrim E, Kilicoglu B, Avci A, Candir O, Durak I. Cisplatinimpairs antioxidant system and causes oxidation in rat kidney tissues: possible protective roles of natural antioxidant foods. J Appl Toxicol. 2006;26:42-6. doi: 10.1002/jat.1103.

44. Sharmin R, Hossain ABM, Momtaz A, Sharmin K, Phil M, Mosaddek ASM. Study on the effect of ethanol extract of Ipomoea aquatica (Kalmi Shak) leaves on gentamicin induced nephrotoxic. J Dent Sci. 2016;1:9-14.

45. Ciccone MM, Cortese F, Gesualdo M, Carbonara S, Zito A, Ricci G, et al. Dietary Intake of carotenoids and their antioxidant and anti-inflammatory effects in cardiovascular care. Mediators Inflamm. 2013;2013:782137. doi: $\quad 10.1155 / 2013 / 782137$.

46. Procházková D, Bousová I, Wilhelmová N. Antioxidant and prooxidant properties of flavonoids. Fitoterapia. 2011;82:513-23. doi: 10.1016/j.fitote.2011.01.018.

47. Rice-Evans CA, Miller NJ, Paganga G. Structure-antioxidant activity relationships of flavonoids and phenolic acids. Free Radic Biol Med. 1996;20:933-56. doi: 10.1016/08915849(95)02227-9.

48. Hajian S. Renoprotective effects of Green tea. J Nephropharmacol. 2013;2:21-22.

Copyright ( 2019 The Author(s); Published by Society of Diabetic Nephropathy Prevention. This is an open-access article distributed under the terms of the Creative Commons Attribution License (http://creativecommons.org/licenses/by/4.0), which permits unrestricted use, distribution, and reproduction in any medium, provided the original work is properly cited. 